\title{
Financial Distress Prediction In Infrastructure, Utilities, And Transportation Sector Companies 2015-2020
}

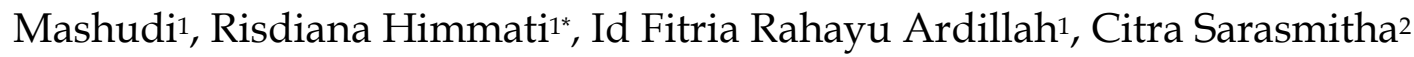 \\ ${ }^{1}$ Faculty of Economics and Business Islam, IAIN Tulungagung, Indonesia. \\ 2Department of Accounting, Faculty of Economics and Business, Universitas Merdeka Malang, \\ Indonesia. \\ *Corresponding Author: risdianahimmati@iain-tulungagung.ac.id
}

\begin{abstract}
This research is based on financial distress or financial distress, which negatively impacts the company, marked by its inability to fulfill its obligations at maturity. This phenomenon can be an early warning related to further problems, and financial distress can be overcome by predicting as early as possible. This prediction is essential for management and company owners to anticipate potential bankruptcy. The formulations in this study include whether inflation affects predicting financial distress in companies in the Infrastructure, Utilities, and Transportation sectors listed on the IDX for the 2015-2020 period. And Whether the financial ratios (Current Ratio, Debt To Equity Ratio, Total Asset Turn Over, Return on Equity, Price Book Value) affects predicting financial distress in Infrastructure, Utilities, and Transportation sector companies listed on the IDX the 2015-2020 period. This study uses a quantitative approach and the type of associative research, and the source data is secondary data with a sample of 10 companies. The sampling technique used purposive sampling. Data processing in this study uses E-Views 9 with Panel Data Regression analysis techniques. This study can conclude that the variables of inflation, current ratio, price-book value, and total turnover significantly affect financial distress in the Infrastructure sector companies: utilities and Transportation. Meanwhile, the debt to equity ratio and return on equity variables did not substantially affect financial distress in the Infrastructure, Utilities, and Transportation sector companies in 2015-2020.
\end{abstract}

Keywords: Inflation; Financial Ratios; Financial Distress

\section{INTRODUCTION}

Financial distress is a condition in which a company cannot fulfill its obligations at maturity or goes into liquidation, which will cause the company to go bankrupt. Financial difficulties can be caused by several facts, namely internal factors seen through the company's financial statements and external factors, which mostly affect both directly and 
indirectly through the macroeconomic variable's inflation variable. (Alfiah \& Diyani, 2018)

Financial distress can be a cruel natural selection that will make a company out of the market if the company is unable to control it, thus making the company go bankrupt. Conditions such as financial distresscan also serve as an early warning system related to further problems. One of the problems is that it will also pose a risk to the growth of the company's market cap, affecting investors' decisions to invest.

Table 1. Company Sectors on the Indonesia Stock Exchange with the Highest Market Cap 20192020 (in billions)

\begin{tabular}{lr}
\hline Company Sector & Market Cap (Billions) \\
\hline Finance (94) & $2,528,669,405$ \\
Consumer Goods Industry (63) & $1,056,642,738$ \\
Basic Industry And Chemicals (80) & $740,626,179$ \\
Infrastructure, Utiities And Transportasion (80) & $707,243,928$ \\
Trade, Service, And Investments (178) & $684,545,899$ \\
\hline
\end{tabular}

Source: Indonesia Stock Exchange , 2019-2020

In table 1, the data on the top five company sectors on the Indonesia Stock Exchange. Companiessector Infrastructure, Utilities, and Transportation is topped ranked fourth in the category of the market cap of the greatest years of 2019-2020. Investors have a great interest in investing in this sector. The great interest of investors in this sector does not mean that they are not vulnerable to financial distress.

It is necessary to develop the model of financial difficulties, given the situation of financial difficulties from the beginning, it is hoped that the company can take action to anticipate this situation so that the company will not enter into a more severe stage of difficulty (Wahyuni et al., 2020). This prediction is essential for company management and owners to anticipate potential bankruptcies. (Aninditya. \& Farida., 2019)

Financial distress can be detected by looking at the company that owns the interest coverage ratio (net income to interest costs) is less than one. Said the company is experiencing financial distress when the interest coverage ratio (ICR) is low or less than 2. It is also not good for corporate profits much out to pay taxes and interest (Faradila \& Aziz, 2016). This means that ICR> 2 is a safe company that does not experience financial difficulties.

Based on this phenomenon and previous research, this study explores the impact of "Inflation and financial performance on forecasting the financial problems of infrastructure, utilities, and transportation companies listed on the Indonesian Stock Exchange, "2015-2020".

\section{LITERATURE REVIEW}

\section{Financial statements}

Financial statements reflect the performance of a company. According to government regulation range eight of 2006 regarding monetary news and therefore the performance of presidency agencies, financial reports are a financial management responsibility for one period. Monetary statements target presenting data regarding a financial position at any given moment (Suwiknyo, 2016). 
Financial statements have benefits to assess the company's ability to meet all liabilities of the company, both short-term and long-term; the company's finances must pay fixed expenses. giving early warning signs as an early sign of bankruptcy in the future (Liang et al., 2020)

There are two types of financial analysis, i.e., a. ) Analytical techniques look for patterns in price history or volume to predict future stock price movements b. ) Fundamental analysis is the process of determining the value of a company by analyzing and explaining the key factors that affect the economy, industry, and company. (Mselmi et al., 2017)

\section{Financial Distress}

Financial distress is the possibility of a company going bankrupt, where it depends on the level of asset liquidity with the availability of credit. (Hendel, 1996) financial distress is a condition in which the company's finances are in a crisis or unhealthy state (Liang et al., 2020). If the company is already in financial distress, management must be careful because it could enter the bankruptcy stage.

Indications of the occurrence of financial distress or financial distress can be seen from a company's financial performance. Financial performance can be obtained from accounting information derived from financial reports. The prediction of financial difficulties illustrates that the variables often used as predictors of bankruptcy can be grouped into 4, namely: financial ratios, macroeconomic variables, corporate governance, and other special variables(Aninditya. \& Farida., 2019).

Indicators to see the condition of financial distress using the interest coverage ratio (ICR). ICR is the ratio between profit before interest and tax on interest expense. This ratio measures the company's ability to meet its fixed expenses in the form of interest with its profits or measures how many times the profit can cover interest expenses(Dinh et al., 2021).

The solution for companies that are indicated to be experiencing financial distress is restructuring. Success in restructuring will stop the decline in the value of the company by reducing debt repayments or replacing the original debt with a number of company securities. The way to reduce debt is by renegotiating the terms of debt repayment with creditors, raising capital, or doing a merger with other companies(Aninditya. \& Farida., 2019)

As for other solutions by means of changes in management, if it is necessary, the company may have to make changes in management with a more competent person. That way, stakeholder trust can return to the company. This is to prevent potential investors from running into financial distress.

\section{Financial Ratio}

Financial Ratio Analysis can predict future events, including the phenomenon of bankruptcy of an entity which has been done by many researchers (Suwiknyo, 2016). Financial ratios are a method of analysis in research used as an indicator for assessing company development. Financial ratios can be used as a tool to assess a company's performance based on a comparison of financial data on available financial statement items. 


\section{Liquidity Ratio}

Liquidity describes the condition of a company that is able to meet its ongoing obligations. Liquidity indicators are usually the current assets, i.e., comparing the total current assets and the total short-term borrowed capital in the company's annual financial statements. A company that is said to be liquid is one that is able to leverage its working capital to generate large profits.

\section{Solvability Ratio}

This index shows the company's ability to meet its long-term obligations. The most commonly used indicator is the debt ratio (DER), which is calculated by comparing total debt to total equity. Debt and long-term debt), while total equity is total equity.

\section{The ratio of activity}

The activities carried out by the company will reflect how efficiently the company uses its assets to generate income. The ratio that is often used in financial distress indicators is Total Asset Turnover (TATO). This ratio measures the extent to which a company's ability to generate company profits; with increasing profits, the increase in return will be obtained by investors.

\section{Profitability ratio}

This ratio illustrates how the company is able to get a profit, which is called profitability. The profitability ratio often used in predicting financial distress is Return On Equity (ROE). This ratio shows the percentage of net income expressed from total equity at the balance sheet date after deducting intangible fixed assets.

\section{Market Ratio}

This ratio reflects how the market assesses the company's performance. The indicator used is Price Book Value (PBV). Price Book Value is the ratio of the stock price to the company's book value. Investors see PBV assess the high or low price of shares offered by the company.

\section{Inflation}

Based on the Keynesian theory of inflation based on his macro theory, inflation occurs because society wants to live outside its economic capacity. According to this view, the inflation process is nothing but a process of seizing a share of the fortune among social groups who want a larger share than what the community can provide.

This struggle process is finally translated into a situation in which the public's demand for goods consistently exceeds the number of goods available, called an inflationary gap. In addition, continuous price increases can also cripple production capacity leading to a production and consumption crisis. The way to measure inflation can be done by using the Consumer Price Index (CPI) approach. The use of CPI is widely used because the data can be obtained in a quarterly or annual form. (Sabrina. Et al. 2019)

\section{Effect of Inflation Against Financial Distress}

Macroeconomic indicators, which are proxied by inflation, illustrate that inflation can affect the company's financial condition due to increased commodity prices in general. This can increase company expenses, such as the purchase of raw materials, which will also increase product sales. Inflation will reduce people's purchasing power, 
which will reduce company sales. The decline in sales followed by an increase in company expenses can threaten the survival of the company so that the company's performance is also affected to be worse. Decreasing company performance causes the company to have the opportunity to experience financial distress.

\section{Effect of Ratio Liquidity Against Financial Distress}

The liquidity magnitude relation, which is proxied by Current plus (CR), describes the condition of an organization that has the flexibility to pay its current liabilities. The larger the ratio of current assets to current debt, the upper the corporate's ability to hide its short liabilities. As a result of the less seemingly the company can cause expertise money distress, it is often aforesaid that it incorporates a sensible performance.

\section{Effect of Ratio of Solvency Against Financial Distress}

The solvency ratio, which is proxied by the Debt to Equity Ratio (DER), shows the ability to pay the company's long-term obligations, calculated by comparing total debt to total equity. A good company should have a larger asset composition than debt, so the company will have less opportunity to face financial distress.

\section{Effect of Ratio Activity Against Financial Distress}

The activity ratio, which is proxied by Total Asset Turnover (TATO), describes the ability of a company to generate company profits; with increasing profits, investors will obtain an increase in return. The higher the ratio, the less likely the company will experience financial distress; it can be said that the company's performance is good.

\section{Effect of Ratios Profitability Of Financial Distress}

The profitability ratio, which is proxied by Return On Equity (ROE), illustrates how the company is able to make a profit; companies that have large profits will certainly avoid financial difficulties. If the ROE value is higher, investors will be more interested in investing their capital. That means that the smaller the company is protected from financial distress.

\section{Effect of Ratio Markets Against Financial Distress}

Market Ratio is proxied by Price Book Value (PBV), reflecting how the market assesses the company's performance. Investors see PBV assess the high or low price of shares offered by the company. Every investor wants a low PBV for a low share price, but a small PBV value is not a guarantee that it will bring big profits to shareholders, but it could be that the low value is because the company has a lot of debt or financial difficulties. This is the importance of predicting financial distress in the company.

\section{HYPOTHESIS}

The hypothesis proposed in this study is a provisional answer to the problem posed theoretically and is considered the most likely based on the indicators of the five financial ratios and the proposed macroeconomic indicators. Therefore, below are explained some of the hypotheses referred to :

$\mathrm{H}_{1}$ : Positive influence of inflation on financial difficulties in the infrastructure, utilities, and transportation sector, which was registered on the Indonesian stock exchange from 2015 to 2020. 
$\mathrm{H}_{2}$ : Positive influence on the circulation coefficient (CR) on financial difficulties in infrastructure, utilities, and transport infrastructure companies, listed on the Indonesian Stock Exchange 2015-2020.

$\mathrm{H}_{3}$ : Debt-to-Equity (DER) positively impacts financial emergencies at infrastructure, utilities, and transportation companies listed on the Indonesian stock exchange in 2015-2020.

$\mathrm{H}_{4}$ : Total revenue (TATO) positively affects financial emergencies in the Infrastructure, Utilities, and Transportation divisions in Indonesian stocks from 2015 to 2020.

$\mathrm{H}_{5}$ : There is a positive return on equity (ROE) effect on emergency financial services in infrastructure, utilities - and transportation companies listed on the Indonesian Stock Exchange 2015-2020.

$\mathrm{H}_{6}$ : The price-book value (PBV) positively affects the prediction of financial problems for companies in the infrastructure, utilities, and transport sectors listed on the Indonesian stock exchange in 2015-2020.

\section{METHOD, DATA, AND ANALYSIS}

This study adopts quantitative methods and related research types. The data source is second-hand data. It uses companies' 2015-2020 annual reports in the infrastructure, public service, and transportation industries. The sample size is ten companies. From the website www.idx.co.id. This study also uses data related to inflation in the study were obtained from the official website of Bank Indonesia, namely www.bi.go.id. The sampling technique used purposive sampling and data processing in this study using E-Views 9 with Panel Data Regression analysis techniques.

\section{RESULTS AND DISCUSSION}

Based on the research method using the deliberate sampling method that meets the requirements to be considered in this research, a total sample of 10 companies was obtained from 50 companies in the Indonesian market's infrastructure, public service, and transportation sectors from 2015 to 2020 - stock market exchange.

\section{Normality test}

Table 2. Normality Test

\begin{tabular}{|c|c|c|}
\hline Indicator & Value & Decision \\
\hline Jarque-Bera & 29.80 & $0.000000<0.05$ \\
\hline Probability & 0.00 & the data in this study are not normally distributed \\
\hline
\end{tabular}

Based on the normality test results in Table 2, the probability value is less than the significance value $(0.000000<0.05)$. It is rejected and accepted, meaning that the data in this study are not normally distributed. One way to solve the problem of abnormal data is by using the trimming method. If the normality assumption is not met, it will be cut or remove outliers (extreme data) on the data (Himmati, 2017). 
Table 3. Trimming Method Normality Test

\begin{tabular}{|c|c|c|}
\hline Indicator & Value & Decision \\
\hline Jarque-Bera & 1.52 & $0.468119>0.05$ \\
\hline Probability & 0.47 & the data in this study are normally distributed \\
\hline
\end{tabular}

Source: Output Eviews 9, 2021

Based on the normality test results in table 3, after using the trimming method by removing outlier data, 52 normal data were obtained. The normality test shows that the Jarque-Bera probability value is greater than significant $(0.468119>0.05)$, meaning that the data in this study are normally distributed.

\section{Heteroscedasticity Test}

Table 4. Heteroscedasticity test results

Prob. Chi-Square (6)

Information

$\mathbf{0 . 2 5 9 6} \quad$ No Heteroscedasticity Problems

Source: Data processed by Eviews 9, 2021

Based on the results of table 4, the results of data processing show the prob value. Chi-Square is 0.2596 , meaning that the regression model is homoscedastic, or in other words, there is no problem with the assumption of heteroscedasticity because the pvalue is $>0.05$.

\section{Chow test}

Table 5. Test Results Test Chow

\begin{tabular}{lrr}
\hline Effect Test & Statistics & Probability \\
\hline Cross-section F & 1.558281 & 0.1655 \\
Chi-square cross-section & 17.107712 & 0.0471 \\
\hline
\end{tabular}

Source: Data processed by Eviews 9, 2021

The results of the Chow test in table 5 show that the probability value of crosssection $\mathrm{F}$ is $0.1655>$ a significance level of 0.05 , so it can be concluded that it is $\mathrm{H}_{\mathrm{O}}$ rejected and $\mathrm{H}_{1}$ accepted, which means that the common effect model is better.

\section{Hausman Test}

Table 6. Hausman Test Test Results

\begin{tabular}{lrr}
\hline Test Summary & Chi-Square Statistics & Probability \\
\hline Random cross-section & 10.602610 & 0.1015
\end{tabular}

Source: Data processed by Eviews 9, 2021

Based on table 6, it is known that the Prob. amounting to $0.1015>$ a significance level of 0.05 , then is $\mathrm{H}_{0}$ rejected and $\mathrm{H}_{1}$ accepted means that the appropriate panel data regression model uses the Random effect model. 


\section{Lagrange Multiplier Test}

Table 7. Lagrange multipliers test results

\begin{tabular}{lrr}
\hline Test Summary & Cross-section & Cross-section Probability \\
\hline Breusch-Pagan & 0.453161 & 0.5008 \\
\hline Source: Data processed by Eviews 9, 2021 & &
\end{tabular}

According to table 7, it is known that the probability of a cross-section breuschpagans at $0.5008>0.05$ significance level is $\mathrm{H}_{\mathrm{O}}$ rejected and $\mathrm{H}_{1}$ accepted means of panel data regression model of the right to use the common effect model.

\section{Partial Regression Coefficient Test ( $t$-test )}

Table 8. T-Statistical Test Results

\begin{tabular}{lrrr}
\hline Variable Name & t-table & t-count & Sig. \\
\hline INFLATION (X1) & 2,3188 & 3.064151 & 0.0037 \\
CR (X2) & 2,3188 & 2.591047 & 0.0129 \\
DER (X3) & 2,3188 & 0.548993 & 0.5857 \\
TATTOOS (X4) & 2,3188 & 3.412492 & 0.0014 \\
ROE (X5) & 2,3188 & 0.398496 & 0.6921 \\
PBV (X6) & 2,3188 & -2.492579 & 0.0176 \\
\hline
\end{tabular}

Source: The data is processed by Eviews 9, the data is processed in 2021

From Table 8, it can be concluded as follows:

Based on the results of the panel data regression analysis test, the result of the $t$ count for the independent variable inflation is 3.064151 using a significant probability level of $\alpha=0.05 / 2=0.025$ (2-sided test), and $\mathrm{gl}=(\mathrm{nk})=(52-7)=45$, where the calculation of the value from table $t$ is 2.3188, which means that the value of count $t$ is greater than the value of table $t$ (3.064151>2.3188), if it is equal to 0.00372 .3188 from the point of view of the probability value.

Furthermore, from the point of view of the probability value, which is 0.01290 .05 , is rejected and accepted, which means that the variable leverage/equity ratio has in some cases no significant effect on financial difficulties. Based on the regression analysis results of the test panel data, the activity ratio represented by Total Sales (TATO) shows that the number $\mathrm{t}$ for the independent variable is 3.412492 using a significant probability level of $\alpha$ $=0.05 / 2=0.025$ (2-sided test) and equ. $=(\mathrm{Nk})=(52-7)=45$, where the calculation of the value of table $t$ of 2.3188 means that the value of count $t$ is greater than the value of table $t$ (3.412492> 2.3188), then seen from the probability value, the 0.0014 .

Based on the results of testing panel data regression analysis, the Profitability Ratio proxied by Return on Equity (ROE) shows the t-count for the independent variable is 0.398496 using a significant level of probability of $\alpha=0.05 / 2=0.025$ ( 2 si si test $)$ and $\mathrm{df}=(\mathrm{nk})=(52-7)=45$, where the $\mathrm{n}$ calculation of the $\mathrm{t}$-table value is 2.3188 . This means that the $t$-count value is smaller than the $t$-table value $(0.398496<2.3188)$, then if it is seen from the probability value that is equal to $0.6921>0.05$, is $\mathrm{H}_{\mathrm{O}}$ rejected and $\mathrm{H}_{1}$ accepted, meaning that the Return On Equity variable partially does not significantly affect financial distress. 
Based on the results of testing panel data regression analysis, the Market Value Ratio proxied by the Price Book Value Ratio (PBV) shows the t-count for the independent variable is -2.492579 using a significant level of probability of $\alpha=0.05 / 2=0.025$ (test 2 side) and $\mathrm{df}=(\mathrm{nk})=(52-7)=45$, where the $\mathrm{t}$-table value calculation is 2.3188 . This means that the $t$-count value is greater than the $t$-table value $(2.492579>2.3188)$, then if it is seen from the probability value, which is equal to $0.0164<0.05$, is $\mathrm{H}_{\mathrm{O}}$ rejected and $\mathrm{H}_{1}$ accepted, meaning that the Price Book Value Ratio variable partially has a significant negative effect. Against financial distress.

\section{Simultaneous Regression Coefficient Test (Test F)}

Table 9. F-Statistical Test Results

\begin{tabular}{lcc}
\hline F-count & F-table & Sig. \\
\hline 4.843782 & 2,3082 & 0.000684 \\
\hline
\end{tabular}

Source: Data processed by Eviews 9, 2021

Based on table 9, it is known that the results of the F Test calculation show that together the independent variables affect the dependent variable. This is evidenced by the value $F_{\text {count }}$ that is equal to 4.843782 with DF1 (N1) $=\mathrm{k}-1=7-1=6$, and DF2 (N2) $=\mathrm{n}-\mathrm{k}$ $=52-7=45$, which is where the calculation of the value of $2.3082 . F_{\text {count }}$ greater than the value $F_{\text {table }}(4.843782>2.3082)$, is $\mathrm{H}_{\mathrm{O}}$ rejected and $\mathrm{H}_{1}$ accepted means to show that together the variables of inflation and five financial ratios include the ratio of liquidity, solvency ratios, activity ratios, profitability ratios, and market ratio effect on the variable financial distress. Based on the Prob significance level. F-Statistics $0.000684<0.05$, then it is $\mathrm{H}_{\mathrm{O}}$ rejected and it $\mathrm{H}_{1}$ means that there is a significant influence simultaneously between the inflation variable and five financial ratios, including the liquidity ratio ( current ratio ), solvency ratio ( debt to equity ratio), activity ratio ( total turnover ), ratio profitability ( return on equity), and the market ratio (price book value) to financial distress variables.

\section{Coefficient of Determination $\left(\mathbf{R}^{\mathbf{2}}\right)$}

Table 10. Calculation Results of the Coefficient of Determination $\left(\mathrm{R}^{2}\right)$

\begin{tabular}{ll} 
R-squared & Adjusted R-squared \\
\hline $\mathbf{0 . 3 9 2 4 0 7}$ & 0.311394
\end{tabular}

Source: Data processed by Eviews 9, 2021

Based on table 10, it can be concluded that the coefficient of determination (RSquared) is shown by the R-Squared value of 0.392407 (39.24\% ). It is also known that the Adjusted R-Square value is 0.311394 (31.3 9\%). This shows that the contribution of the independent variables consisting of inflation and five financial ratios includes the liquidity ratio ( current ratio ), solvency ratio (debt to equity ratio), activity ratio ( total turnover), profitability ratio (return on equity), and the ratio market (price book value) to the financial distress variable of $39.24 \%$. The rest $(100 \%-39.24 \%=60.76 \%)$ is influenced by other variables outside those proxied by the researcher.

\section{Effect of Inflation on Financial Distress}

The results of the study indicate that the inflation variable affects financial distress. Inflation occurs because society wants to live beyond its economic limits. Apart 
from that, the continuous increase in prices can also cripple production capacity leading to a production and consumption crisis (Pertiwi, 2018)

The higher the inflation rate, the higher the financial distress value. That is, in this study, the increase in inflation will result in the company going bankrupt. The increase in the prices of goods triggers someone to refrain from shopping. This condition causes the products produced by the company to be unsold. In other words, under conditions of inflation, company revenues will decrease due to people's behavior withholding spending.

The drive theory explains that a person's behavior requires a boost. The increase in the prices of goods encourages people to exert themselves to shop. Thus, inflation causes the company's profitability to decline, and the possibility of financial distress will be even greater.

The results of this study are also in line with Keynes's theory of inflation which is based on his macro theory. The higher the amount of inflation, the higher the economic growth. The results of this study are in line with research conducted by Firdaus (2019), explaining that inflation has an effect on financial distress. The factor causing full demand inflation is the high demand for goods and services relative to their availability. This has an impact on raw material companies that depend on imported goods so that it can cause the company to spend more and put the company in a financial distress position.

However, the results of this study are contrary to the research conducted by Kurniasanti ( 2018 ), which states that the inflation variable does not have a significant effect on financial distress. Because in an analysis of inflation that occurred during the study period was not so high or tended to be stable so that the company could still control and anticipate the condition.

\section{Effect of Current Ratio (CR) Into Financial Distress}

This study indicates that the liquidity ratio variable, as proxied by the current ratio (CR), significantly affects financial distress. The variable current ratio with financial distress forms a negative relationship. This means that the higher the current ratio, the lower the financial distress. Conversely, the lower the current ratio, the higher the financial distress.

Companies with high liquidity will be easy to develop because liquidity will help the company settle its current obligations. In addition, high liquidity also makes it easier for companies to process raw materials to make sales because of the ease in paying capital costs. Thus, high liquidity will lead to high profitability, and the possibility of financial distress will be lower.,

The results of this study are in line with research conducted by Sri Fitri ( 2020 ), and Tio N. (2014) current ratio (CR) has a significant effect on financial distress. Sach decrease in the current ratio of the possibilities of Companies Companies experiencing financial distress even greater. If the higher the current ratio will sem a cloth also high levels of liquidity the company. A company that does not have sufficient funds to cover the payments due to be experiencing financial difficulties.

The results of this study contradict the research conducted by Muhammad Sanyasa. et al. ( 2020 ) explain that the liquidity ratio proxied by the current ratio (CR) does not significantly affect financial distress. D nature of research occurs because the 
calculation of inventory and accounts receivable business has a long duration and manner that is not the same for each company. Therefore, the study of the rise and decline in the value of liquidity will not impact the potential conditions of financial distress.

\section{Effect of Debt To Equity Ratio (DER) on Financial Distress}

The research results show that the solvency ratio variable, proxied by the debt to equity ratio (DER), does not affect financial distress.

The level of DER in this study does not affect financial distress. Companies that have large debts tend to use the proceeds from the loan prudently. The company will look for strategies so that the cost of the debt-money will be lower than the income earned from the debt. Thus, the cost of debt that arises can be covered by the circulation of money obtained from this debt.

The company will invest the money from the bank loan into investments that generate higher returns than the cost of debt. This is in line with the drive theory that the interest costs incurred on this debt will encourage companies to be very careful in using the money from the loan. Thus, DER has no effect on financial distress.

The results are consistent with the empirically n conducted by Sri Fitr (2020), and Alfiah K. (2018) stated that the debt to equity ratio has no effect on financial distress because its capital can cover the total debt owned by the company in the study. So that whatever the capital owned by the company has guaranteed the borrowed liabilities.

\section{Effect of Total Turn Over (TATO) on Financial Distress}

The research result shows that the activity ratio variable, which is proxied by total turnover (TATO), significantly affects financial distress. The higher the TATO value, the lower the financial distress value. Conversely, the lower the TATO, the higher the value of financial distress.

The results of this study are in line with research conducted by Rizky K. ( 2019 ) and Tio N. (2014), explaining that the total turnover (TATO) variable has a significant effect on financial distress. This study indicates that the smaller the total turnover value can lead to financial distress; the higher this ratio, the more efficient the use of assets and the faster the withdrawal of funds in cash. The results of this study contradict research conducted by Aninditya, C., (2019), explaining that the activity ratio variable, which is proxied by total turnover (TATO), does not have a significant effect on financial distress. A Value of the total turnover ratio, these companies can experience financial distress. There will be a cost of financial distress.

\section{Effect of Return On Equity (ROE) on Financial Distress}

The research results show that the variable earnings index represented by the return on equity (ROE) has no significant impact on financial issues. The results of this study are consistent with the research conducted by Sri Fitri. et al. (2020) and Tio N. (2014) explains that return on equity does not affect financial distress. This is a decrease in net income in proportion to the increase in the equity each year.

This means that return on equity directly impacts a company's financial distress because the higher the equity contribution means, the higher the amount of net profit generated. The results of this study contradict the research conducted by Listyorini 
Wahyu; the result is that return on equity has a significant positive effect on financial distress because the high and low value of return on equity in her research has an impact on financial distress.

\section{Effect of Price Book Value (PBV) on Financial Distress}

Research shows that variable market value ratios represented by book value (PBV) significantly impact financial issues. The results of this study are consistent with the research conducted by Oktarina (2019) and Mulya Y. (2019), explaining that the hypothesis is accepted and the price book value influences financial distress.

This research shows that the higher the company's value, the more likely it is to get into financial trouble.

Effect of Inflation, Current Ratio, Debt To Equity Ratio, Total Turnover Return On Equity d's Price Book Value In Simultaneous to the Financial Distress

According to the results of the simultaneous test, the results show that inflation variables and five financial ratios include liquidity ratio (liquidity ratio), solvency ratio (debt/equity ratio), activity ratio (total sales), profitability (and equity), Comparative profitability) and market quotas (book value of prices) have a significant impact on the variables of the financial crisis. Companies in the infrastructure, services, and transportation sectors can see a relevant definition of $36.31 \% .100 \% 36.31 \%=63.69 \%$ ) depends on other variables unrelated to the researcher's variables.

The higher the current ratio, the lower the value of financial distress will be. A high current ratio will make it easier for companies to turn their capital to make a profit that ensures business continuity in the future. Meanwhile, high-interest costs will encourage companies to be very careful in using cash from debt. Thus, high-interest costs encourage companies to increase their profitability.

\section{CONCLUSION AND SUGGESTIONS}

Inflation affects the financial difficulties of infrastructure, utilities, and transportation companies listed on the Indonesian Stock Exchange from 2015 to 2020. In 2015-2020, the inflation rate fluctuated and tended to slow down, followed by interest coverage below 2. This figure shows that the company's interstellar coverage is in poor condition because the company's profits are generally reduced for expenses, taxes, and interest. This situation caused the company to fall into financial distress.

The current liquidity ratio significantly impacts the financial difficulties of infrastructure, utilities, and transportation companies listed on the Indonesian Stock Exchange from 2015 to 2020. The current liquidity ratio of the company under review is less than 3, which means that the short-term debt of a one-rupee company can cover three-rupee working capital. The lower the value of the current liquidity ratio, then the lower the company's ability to pay the short-term debt. The current decline in the liquidity ratio causes the company financial difficulties.

The leverage ratio (DER) has no impact on companies' financial difficulties in the infrastructure, public services, and transportation sectors listed on the Indonesian Stock Exchange from 2015 to 2020 . The higher the DER value, the more the company is inclined 
to debt financing. Companies pay higher interest costs. Companies that can use debt financing benefit more than companies that use equity financing because the cost of debt is lower than the resulting profitability, which means an increase or decrease in leverage.

(DER) will not cause any financial difficulties to the company. The total asset turnover ratio (TATO) has a significant positive impact on the financial conditions of companies in the infrastructure, utilities, and transportation industries listed on the Indonesian Stock Exchange from 2015 to 2020. The higher the TATO, the more financial problems the company has. The TATO index number of the observed company is less than 1, indicating that the company's efficiency has decreased, which means that the ability to observe the company's financial problems has decreased. The value of the activity index can predict the occurrence of a company's financial difficulties.

The return on equity (ROE) has no significant impact on the financial status of infrastructure, utilities, and transportation companies listed on the Indonesian Stock Exchange from 2015 to 2020. The ROE value does not affect the financial status. Infrastructure, utilities, and transportation companies listed on the Indonesian Stock Exchange from 2015 to 2020.

The book value of (PBV) has a significant impact on financial issues. The book value of the observed company is greater than 1, indicating that the stock price is higher. The higher stock price allows potential investors to reconsider their investment. Therefore, the company will not have new investors because the purchase of the company's stock is expensive and considered overpriced.

With this research, companies that are indicated to be in financial distress must immediately follow up on the company's financial condition by increasing the value of the company's obligations and profits to avoid financial distress. e.g., the infrastructure, utilities, and transportation sectors Company. And this research can be used as insight and reference for investors in making decisions to invest in the company.

For Academics. This research is expected for academics, especially for students of Islamic financial management, can be used as a reference if they want to do the same research, and can be used as additional knowledge about predictions of corporate financial health. This research can be used as an insight for students in learning to start investing, in investing not only seen in the distribution of company dividends but also critically understand which companies are experiencing financial difficulties.

Suggestions and hopes for future researchers, It is hoped to increase the number of samples, periods, and variables to produce more accurate information and use other prediction models.

\section{REFERENCES}

Alfiah, N., \& Diyani, L. A. (2018). Pengaruh Roe Dan Der Terhadap Harga Saham Pada Sektor Perdagangan Eceran. Jurnal Bisnis Terapan, 1(02), 47-54. https:// doi.org/10.24123/jbt.v1i02.794

Aninditya., N. C., \& Farida., K. T. (2019). FAKTOR DETERMINAN DARI COST OF FINANCIAL DISTRESS (Studi Empiris pada Perusahaan Tekstil dan Garmen di Indonesia Tahun 2014-2017). Journal Accounting and Finance, 03(1), 25-34. 
https:// doi.org/10.25124/jaf.v3i2.2208

Dinh, D. V, Powell, R. J., \& Vo, D. H. (2021). Forecasting corporate financial distress in the Southeast Asian countries: A market-based approach. Journal of Asian Economics, 74, https:// doi.org/10.1016/j.asieco.2021.101293

Faradila, P., \& Aziz, A. (2016). Analisa Kinerja Keuangan Terhadap Prediksi Financial Distress Ukuran Perusahaan. Jurnal Ekonomi Dan Bisnis, 3(1), 27-38. https:// dx.doi.org/10.35590/jeb.v3i1.722

Himmati, R. (2017). the Analysis of Agricultural Products in Pineapple Commodities in Ngancar District, Kediri Regency, East Java Province. Journal of Indonesian Applied Economics, 7(1), 48-58. https:/ / doi.org/10.21776/ub.jiae.2017.007.01.3

Kartika, R., \& Hasanudin. (2019). Analisis Pengaruh Likuiditas, Leverage, Aktivitas Dan Profitabilitas Terhadap Financial Distress Pada Perusahaan Terbuka Sektor Infrastruktur, Utilitas, Dan Transportasi Periode 2011-2015. Jurnal Ilmu Manajemen Oikonomia, 15(1), 1-16.

Kurniasanti, A., \& Musdholifah, M. (2018). Pengaruh Corporate Governance, Rasio Keuangan, Ukuran Perusahaan Dan Makro ekonomi Terhadap Financial Distress (Studi Pada Perusahaan Sektor Pertambangan Yang Terdaftar di Bursa Efek Indonesia Tahun 2012-2016). Jurnal Ilmu Manajemen, 6(3), 197-212.

Liang, D., Tsai, C.-F., Lu, H.-Y. (Richard), \& Chang, L.-S. (2020). Combining corporate governance indicators with stacking ensembles for financial distress prediction. Journal of Business Research, 120, 137-146. https:// doi.org/10.1016/j.jbusres.2020.07.052

Mselmi, N., Lahiani, A., \& Hamza, T. (2017). Financial distress prediction: The case of French small and medium-sized firms. International Review of Financial Analysis, 50, 67-80. https://doi.org/10.1016/j.irfa.2017.02.004

Noviandri, T. (2014). Peranan Analisis Rasio Keuangan Dalam Memprediksi Kondisi Financial Distress Perusahaan Sektor Perdagangan. Jurnal Ilmu Manajemen, 2, 16551665.

Oktarina, D. (2019). Peran Nilai Perusahaan Dalam Menentukan Pengaruh Kinerja Perusahaan Terhadap Financial Distress Di Asean. Jurnal Profita, 12(3), 476. https:// doi.org/10.22441/profita.2019.v12.03.009

Pertiwi, D. A. (2018). Pengaruh Rasio Keuangan, Growth, Ukuran Perusahaan, dan Inflasi Terhadap Financial Distress di Sektor Pertambangan Yang Terdaftar DI Bursa Efek Indonesia (BEI) Periode 2012-2016. Jurnal Ilmu Manajemen (JIM), 6(3), 359-366. https://jurnalmahasiswa.unesa.ac.id/index.php/jim/article/view/24314

Piatt, H. D., \& Piatt, M. B. (2002). Predicting corporate financial distress: Reflections on choice-based sample bias. Journal of Economics and Finance, 26(2), 184-199. https://doi.org/10.1007/bf02755985

Piatt, H. D., Piatt, M. B., Publishing, B., Journal, T., Economics, I., Kurniasanti, A., Musdholifah, M., Tyaga, M. S., Kristanti, F. T., Wahyuni, S. F., Farisi, S., Jufrizen, Faradila, P., Aziz, A., Kartika, R., Hasanudin, Noviandri, T., Rohiman, S. F., Damayanti, C. R., ... Yulistina. (2019). Peran Nilai Perusahaan Dalam Menentukan 
Pengaruh Kinerja Perusahaan Terhadap Financial Distress Di Asean. Jurnal Ilmu Manajemen, 2(2), 197-212. https:/ / doi.org/10.1007/bf02755985

Purnama, D., Hamzah, A., Puspasari, O., Nurfatimah, S., \& Nurhayati, E. (2021). Free Cash Flow, Financial Distress and Debt Policy Toward Earnings Management in Indonesian Banking Sector. European Union Digital Library. https:// doi.org/10.4108/eai.12-12-2020.2305112

Rohiman, S. F., \& Damayanti, C. R. (2019). Pengaruh Inflasi, Nilai Tukar Dan Suku Bunga Terhadap Financial Distress. Jurnal Administrasi Bisnis, 72(2), 186-195.

Supriyanto, J., \& Darmawan, A. (2018). The Effect of Financial Ratios on Financial Distress in Predicting Bankruptcy. Journal of Applied Managerial Accounting, 2(1), 110-120. https:// doi.org/10.30871/jama.v2i1.727

Suwiknyo, D. (2016). Analisis Laporan Keuangan Perbankan Syariah. Pustaka Pelajar.

Tyaga, M. S., \& Kristanti, F. T. (2020). Analisis Survival Dalam Memprediksi Kondisi Financial Distress. Buletin Studi Ekonomi, 25(1), 112. https:// doi.org/10.24843/bse.2020.v25.i01.p07

Udin, S., Khan, M. A., \& Javid, A. Y. (2017). The effects of ownership structure on the likelihood of financial distress: empirical evidence. The International Journal of Business in Society, 17(4), 589-612. https:// doi.org/10.1108/CG-03-2016-0067

Wahyuni, S. F., Farisi, S., \& Jufrizen. (2020). Faktor determinan financial distress pada perusahaan sektor manufaktur yang terdaftar di bursa efek indonesia Determinants of financial distress in manufacturing sector companies registered on the indonesia stock exchange. Jurnal Ekonomi Keuangan dan Manajemen 16(2), 286-298.

Yulitasari R.M, \& Yulistina. (2019). Pengaruh Kinerja Keuangan Terhadap Financial Distress Pada Perusahaan Sektor Semen Listed BEI 2012-2017. Jurnal Media Ekonomi, 24(2), 18-26. https:// doi.org/10.32767/JURMEK.V24I2.565 